\title{
PENENTUAN KEDALAMAN BATUAN DASAR MENGGUNAKAN METODE GEOLISTRIK TAHANAN JENIS DENGAN MEMBANDINGKAN KONFIGURASI DIPOLE-DIPOLE DAN WENNER DI BUKIT APIT PUHUN KECAMATAN GUGUK PANJANG KOTA BUKITTINGGI
}

\author{
Harman Amir ${ }^{1}$, Akmam $^{2}$, Bavitra ${ }^{3}$, Mia Azhari ${ }^{4}$ \\ ${ }^{1)}$ Staf Pengajar Jurusan Fisika FMIPA UNP , email: harman_unp@yahoo.com; \\ akmamdb@fmipa.unp.ac.id \\ ${ }^{2)}$ Mahasiswa Jurusan Fisika FMIPA UNP, email: bavitra_panai@yahoo.com; \\ miaazhari31@yahoo.co.id
}

\begin{abstract}
Bukit Apit Puhun Bukittinggi area is located at Sianok fault zone. This area is potensially occur tectonic activity such as earthquakes. Tectonic activity could disturb the stability of the bedrock. The aim of this research was to determine the resistivity and to depth of basement bedrock in Bukit Apit Puhun Bukittinggi area. This research used Robust 2D inversion Geoelectrical data with Dipole-dipole configuration and Smoothness-Constraint Least Squares with Wenner configuration. The Data of this research were taken five track using ARES (Automatic Resistivitymeter). Each of data were processed and interpreted with using Robust 2D and Smoothness-Constraint Least Squares inversion. The result of this research showed that type of basement bedrock in Bukit Apit Puhun Guguk Panjang was an igneous groups, namely Andesite. Resistivity of Andesite bedrock were varies on the each track. The resistivy of Andesite was 345 m - 39.039 m. Dephts of Andesite bedrock were varies, which generally more than 30 meters deepness at Bukit Apit Puhun Bukittinggi area.
\end{abstract}

Keywords : Basement Rocks, Resistivity, Dipole-dipole, Wenner, Robust Inversion, Smoothness-Constraint Least Squares

\section{PENDAHULUAN}

Bukit Apit Puhun Kecamatan Guguk Panjang Kota Bukittinggi merupakan daerah yang terletak di jalur patahan Ngarai Sianok yang mempunyai tingkat resiko tinggi terjadi bencana gempabumi. Sumber gempabumi di Ngarai Sianok adalah patahan yang berada disepanjang daerah Ngarai Sianok. Patahan merupakan zona rekahan kerak bumi dimana bagian bumi di kedua sisi rekahan tersebut bergerak satu dengan yang lainnya. Patahan inilah nantinya akan menimbulkan sumber gempabumi $^{[1]}$. Gempabumi yang dasyat akan mengakibatkan berubahnya susunan lapisan bumi ${ }^{[2]}$. Gempabumi diperkirakan dapat menyebabkan berubahnya struktur batuan terutama batuan dasar dibawah permukaan bumi.

Batuan dasar memiliki peranan penting dalam perencanaan pembangunan infrastruktur pada suatu daerah. Jenis dan kedalaman batuan dasar di bawah permukaan bumi dapat dijadikan sebagai bahan pertimbangan dalam membangun suatu infrastruktur. Keberadaan batuan dasar dapat dijadikan pedoman dalam kontruksi jalan raya dan bangunan ${ }^{[3]}$. Sifat batuan dasar yang memiliki tekstur keras, sehingga dapat dijadikan sebagai acuan dalam pemberian beban terhadap permukaan bumi akibat pembangunan infrastruktur di atas permukaannya.

Batuan dasar memiliki pondasi yang kuat bagi lapisan batuan yang ada diatasnya. 
Batuan dasar adalah batuan yang tersingkap di sekitar gunung api dan sebagai alas dari jenis batuan yang dihasilkan oleh gunung api tersebut ${ }^{[4]}$. Batuan dasar sulit ditemukan pada daerah permukanan karena adanya proses pelapukan, sehingga singkapan batuan dasar tertutupi oleh tanah dan banyaknya vegetasi lain ${ }^{[5]}$. Batuan dasar umumnya menjadi dasar dan landasan batuan yang ada di atasnya.

Batuan dasar memiliki porositas dan permeabilitas yang sangat rendah. Rendahnya nilai porositas batuan dasar memungkinkan terjadinya porositas sekunder. Porositas sekunder yang terjadi pada batuan dasar dibagi atas 2, yaitu Porositas Tektonik dan Dissolution Porosity. Porositas Tektonik, yaitu berupa patahan, sesar dan sebagainya. Dissolution Porosity yaitu efek dari adanya pelarutan pada wilayah pelapukan ${ }^{[6]}$. Porositas adalah ukuran ruang kosong dalam suatu bahan, sedangkan permeabilitas adalah sifat suatu bahan untuk meloloskan air. Nilai porositas batuan dasar berkisar antara $0,1 \%-1 \%$ dan nilai permeabilitas batuan dasar kecil dari $0,5 \%$ kecuali pada zona lapuk yaitu 5\% $10 \%{ }^{[7]}$. Nilai porositas dan permeabilitas yang rendah meyebabkan batuan kurang memiliki pori dan kurang menyerap air sehingga arus listrik sedikit mengalir melalui batuan dasar.

Batuan dasar dapat berupa batuan beku, batuan sedimen maupun metamorf. Batuan beku adalah batuan yang terbentuk dari pembekuan magma cair dari dalam bumi $^{[}$. Batuan sedimen adalah batuan yang terjadi karena pengendapan materi yang dialirkan oleh air, udara dan es sehingga terjadi perubahan fisik dan kimiawi. Batuan Metamorf merupakan batuan sedimen yang telah mengalami transformasi akibat adanya pengaruh perubahan suhu, tekanan, cairan atau gas aktif ${ }^{[8]}$. Batuan dasar merupakan batuan yang paling tua diantara batuan yang ada disekitar wilayahnya

Nilai tahanan jenis untuk batuan bervariasi. Secara umum berdasarkan harga tahanan jenis dalam menghantarkan arus listrik, batuan dapat dikelompokkan menjadi tiga, yaitu : konduktor baik dengan harga tahanan jenis $\left(10^{-8} \Omega \mathrm{m}<\rho<1 \Omega \mathrm{m}\right)$, semi konduktor memiliki harga tahanan jenis ( $\left.1 \Omega \mathrm{m}<\rho<10^{7} \Omega \mathrm{m}\right)$, dan isolator $\left(\rho>10^{7}\right.$ $\Omega \mathrm{m})$. Batuan beku jenis Andesite memiliki nilai tahanan jenis $170-4,5 \times 10^{4}{ }^{[9]}$. Batuan beku dan batuan metamorf memiliki konduktivitas lebih kecil dibandingkan batuan sedimen.

Keberadaan dan jenis batuan dasar penyusun lapisan bawah permukaan bumi dapat diestimasi menggunakan metode Geolistrik Tahanan yang dilakukan dengan menginjeksikan arus listrik kedalam permukaan bumi dan mengukur beda potensial yang ditimbulkan di permukaan bumi $^{[10]}$. Tahanan jenis lapisan batuan bawah permukaan bumi dihitung dengan menggunakan hukum Ohm, maka nilai tahanan jenis dapat diidentifikasi batuan penyusun lapisan bawah permukaaan bumi.

Tahanan jenis yang diperoleh dari pengukuran metode Geolistrik Tahanan Jenis merupakan tahanan jenis semu, dengan mengasumsikan bumi sebagai medium homogen dan isotropis. Tahanan jenis semu tidak secara langsung me-nunjukkan nilai tahanan jenis medium, namun mencerminkan distribusi nilai tahanan jenis medium dengan Persamaan (1) di bawah adalah tahanan jenis semu (apparent resitivity, $\left.\rho_{a}\right)^{[11]}$. Tahanan jenis semu dilambangkan dengan $\rho_{a}$, dirumuskan pada Persamaan (1)

$$
\rho_{a}=K \frac{\Delta V}{I}
$$

nilai K pada persamaan (1) adalah:

$$
\mathrm{K}=2 \pi\left\{\left(\frac{1}{\mathrm{r}_{1}}-\frac{1}{\mathrm{r}_{2}}\right)-\left(\frac{1}{\mathrm{r}_{3}}-\frac{1}{\mathrm{r}_{4}}\right)\right\}^{-1}
$$

$\mathrm{K}$ merupakan faktor geometri yang merupakan susunan elektroda. Beberapa susunan elektroda yang digunakan dalam pengukuran resistivitas adalah konfigurasi Dipole-dipole dan Wenner. Susunan elektroda pada konfigurasi Dipole-dipole 
dan Wenner dapat dilihat pada Gambar 1 berikut:
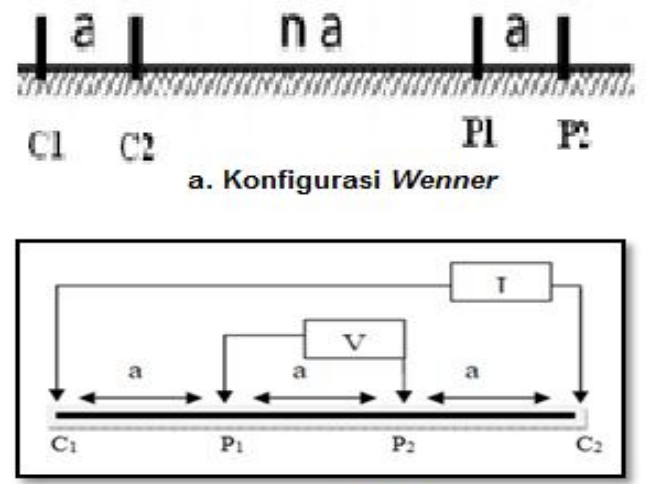

b. Konfigurasi Dipole-dipole

Gambar 1. Susunan Elektroda pada Konfigurasi Dipole-dipole $e^{[12]}$ dan Wenner $^{[13]}$.

Gambar 1 menunjukkan susunan pemasangan elektroda potensial pada pengukuran dengan metode Geolistrik. Pada konfigurasi Dipole-dipole Besar jarak $\boldsymbol{r}_{1}, \boldsymbol{r}_{2}$, $\boldsymbol{r}_{3}$, dan $\boldsymbol{r}_{4}$ dari Gambar 1 adalah:

$r_{1}=n a+a=a(n+1) ; r_{2}=n a$

$r_{3}=2 a+n a=a(n+2) ; r_{4}=n a+a=$ $a(n+1)$

Sedangkan pada konfigurasi Wenner untuk jarak

$\mathrm{r}_{1}=\mathrm{a}, \mathrm{r}_{2}=2 \mathrm{a}, \mathrm{r}_{3}=2 \mathrm{a}$, dan $\mathrm{r}_{4}=\mathrm{a}$,

Persamaan (3) dan (4) masing-masing disubstitusikan ke Persamaan faktor Geometri pada Persamaan (2), dan setelah mendapatkan nilai $\mathrm{K}$ di substitusikan ke Persamaan (1), sehingga akan diperoleh nilai tahanan jenis semu untuk masingmasing konfigurasi. konfigurasi Dipoledipole seperti Persamaan (5a) dan Konfigurasi Wenner pada Persamaan (5b).

$$
\begin{aligned}
& \rho_{a}=\pi a n(n+1)(n+2) \frac{\Delta V}{I} \\
& \rho_{a}=2 \pi a \frac{\Delta V}{I}
\end{aligned}
$$

Konfigurasi Dipole-dipole memiliki kemampuan penetrasi $1 / 5$ dari panjang lintasan. Selain itu, konfigurasi Dipole- dipole merupakan konfigurasi yang paling teliti, terutama untuk mendeteksi struktur vertikal dan memiliki resolusi tertinggi yang memungkinkan untuk membedakan struktur yang terletak lebih dalam ${ }^{[14]}$. Konfigurasi Wenner mempunyai keunggulan dalam tingkat sensitivitas terhadap pengaruh nonhomogenitas benda di bawah permukaan bumi secara lateral dan memiliki resolusi vertikal yang bagus ${ }^{[15]}$. Keunggulan konfigurasi Wenner menyebabkan konfigurasi Wenner cocok di-gunakan untuk mengidentifikasi jenis batuan di-bawah permukaan bumi pada setiap lapisan.

Data lapangan yang diperoleh saat pengukuran mengandung informasi mengenai sifat-sifat fisis batuan. Informasi batuan yang diperoleh dari data lapangan diinterpretasi menggunakan Metode inversi yang digunakan adalah metode inversi Robust Constraint pada konfigurasi Dipoledipole dan Smoothness-Constraint Least Squares Konfigurasi Wenner. Inversi Robust sangat baik digunakan dalam interpretasi daerah antar batas antar lapisan bawah permukaan bumi yang berbeda ${ }^{[16]}$. Namun inversi ini kurang sensitif terhadap error pengukuran yang besar dibandingkan dengan metode Least Squares ${ }^{[17]}$. Nilai error tersebut dapat diperkecil dengan damping factor yang tepat dalam pengolahan data, sehingga hasilnya lebih mendekati data yang sebenarnya.

Potensial pada model bumi berlapis dinyatakan dengan persamaan $(6)^{[18]}$.

$$
U(r)=\frac{l}{2 \pi} \int_{0}^{\infty} T(\lambda) J_{0}(\lambda r) d \lambda
$$

$U(r)$ adalah fungsi beda potensial terhadap lapisan perlapisan bawah permukaan bumi. Besarnya tahanan jenis semu akibat injeksi arus dapat dinyatakan dalam Persamaan $(7)^{[19]}$.

$$
\rho_{a}(s)=s^{2} \int_{0}^{\infty} T(\lambda) J_{0}(\lambda r) \lambda d \lambda
$$

dimana $\mathrm{S}$ adalah jarak elektroda arus. Fungsi transformasi tahanan jenis dinyatakan seperti Persamaan (8). 


$$
T(\lambda)=\int_{0}^{\infty} \frac{1}{s} \rho_{a}(s) J_{0}(\lambda r) d s
$$

(8)

dimana $T(\lambda)$ adalah fungsi transformasi dari tahanan jenis semu, juga merupakan fungsi yang bergantung pada parameter-parameter lapisan (tahanan jenis dan ketebalan). $J_{0}(\lambda r)$ merupakan fungsi Bessel orde nol. Inversi Robust dinyatakan oleh Persamaan $(9)^{[20]}$.

$$
\left(J^{T} J+\lambda F_{R}\right) \Delta q=J^{T} R g-\lambda F_{R} q
$$

Data hasil pengukuran diinterpretasikan menggunakan Inversi Smoothness-Constraint Least Squares dinyatakan oleh Persamaan (10) ${ }^{[20]}$.

$\left(\mathrm{J}^{\mathrm{T}} \mathrm{J}+\mu \mathrm{F}\right) \Delta \mathrm{m}_{\mathrm{k}}=\mathrm{J}^{\mathrm{T}} \mathrm{d}-\mu \mathrm{Fr}$

dimana $R_{d}$ adalah matriks untuk mempertajam batasan antar lapisan, J merupakan matrik Jacobian dari turunan parsial, $\lambda$ adalah faktor damping, $\Delta \mathrm{q}$ adalah vektor perubahan parameter model dan $\mathrm{g}$ vektor dispersi. Vektor dispersi $\mathrm{g}$ merupakan perbedaan antara nilai-nilai tahanan jenis yang diukur dan yang dihitung. Besarnya vektor ini sering diberikan sebagai nilai RMS (root meansquare). Vektor perturbasi $\Delta \mathrm{q}$ adalah perubahan nilai tahanan jenis model yang dihitung. $\mu$ merupakan faktor damping yang berfungsi untuk mempercepat proses konvergensi ${ }^{[11]}$.

\section{METODE PENELITIAN}

Penelitian ini merupakan penelitian dasar yang bersifat deskriptif. Penelitian ini dilaksanakan di Bukit Apit Puhun kecamatan Guguk Panjang kota Bukittinggi. Parameter yang diukur pada penelitian ini adalah kuat arus listrik (I), beda potensial $(\boldsymbol{V})$ dan spasi jarak elektroda. Parameter yang dihitung pada penelitian ini adalah kedalaman batuan dasar dan tahanan jenis semu $\left(\boldsymbol{\rho}_{\boldsymbol{a}}\right)$. Lintasan yang tersebar di beberapa titik pengukuran dapat dilihat pada Gambar 2.

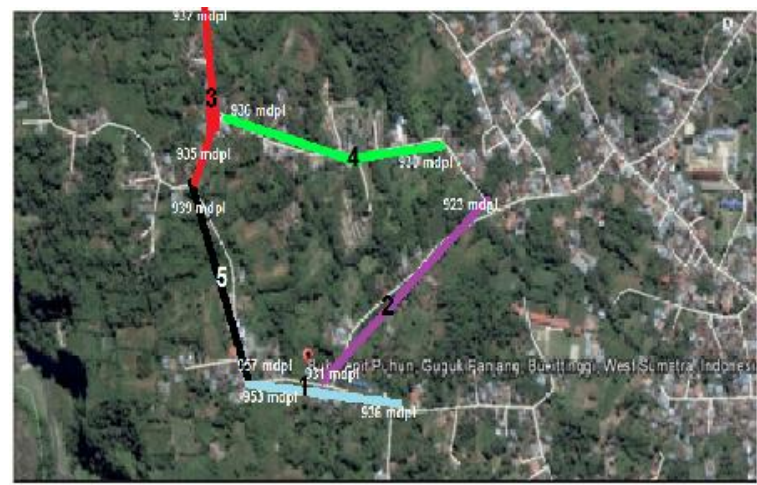

Gambar 2. Desain Lintasan Pengukuran. Sumber: (Google map)

Pada Gambar 2 pemilihan Lintasan 3 yang terpencil atau agak menyebar dengan keempat Lintasan yang lain disebabkan pada Lintasan ini masih sedikit dibangun infrastruktur jalan dan bangunan, sehingga perlu dilakukan penelitian tentang keberadaan dan jenis batuan dasar. Informasi tersebut dapat dijadikan sebagai bahan pertimbangan dalam membangun infrastruktur pada daerah kosong disekitar Lintasan ini.

Data yang didapatkan pada saat melakukan pengukuran tersimpan pada ARES Main Unit. Data yang diperoleh diinterpretasikan menggunakan metode inversi. Metode inversi dilakukan dengan bantuan program Res2dinv. Res2dinv merupakan suatu program komputer yang dapat menentukan penampang model 2D bawah permukaan bumi berdasarkan nilai tahanan jenis semu di sepanjang Lintasan pengukuran. Metode inversi yang digunakan adalah metode inversi Robust Constraint pada konfigurasi Dipole-dipole dan Smoothness-Constraint Least Squares Konfigurasi Wenner.

\section{HASIL PENELITIAN DAN PEMBAHASAN}

\section{A. Hasil}

\section{Lintasan 1}

Lintasan 1 memiliki panjang Lintasan $280 \mathrm{~m}$, dimulai pada koordinat dari $00^{\circ} 17^{\prime}$ 55,9” LS dan $100^{\circ} 25^{\prime} 15,6$ " BT dengan ketinggian 936 mdpl sampai koordinat $00^{\circ}$ 
17' 50,5" LS dan

$100^{0} 21^{\prime} 21,06^{\prime \prime}$

BT dengan ketinggian $953 \mathrm{mdpl}$ dengan spasi elektroda 5 meter. Gambar 3 menunjukkan penampang model 2D Lintasan 1.
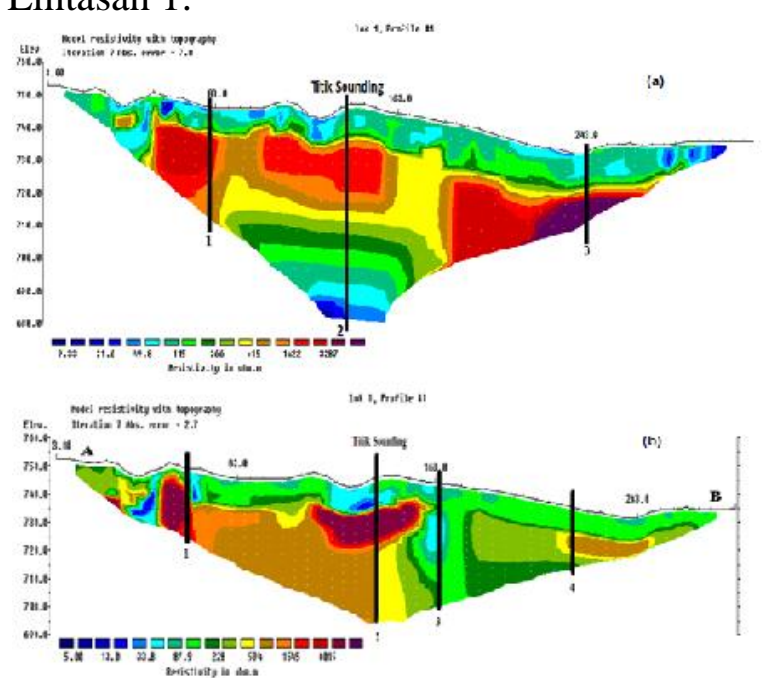

Gambar 3. Penampang Model 2D Lintasan 1 dengan Konfigurasi Dipole-dipole dan Wenner

Berdasarkan Gambar 3a dapat dilihat penampang $2 \mathrm{D}$ bawah permukaan sepanjang Lintasan 1 dengan kedalaman yang dicapai adalah 55,35 m. Lintasan 1 memiliki rentangan nilai tahanan jenis dari 4,665 m - 4287 m dengan persentase kesalahan 7,8 $\%$ pada iterasi ke 7 . Lintasan 1 memiliki standar deviasi $0,1 \%$ dan $15,7 \%$. Lintasan 1 memiliki standar deviasi $15,7 \%$ menunjukkan data yang sedikit kurang homogen. Namun standar deviasi pada penelitian ini termasuk pada tingkat kepercayaan tinggi dikarenakan nilai standar deviasi hasil penelitian yang kecil.

Pada Lintasan 1 batuan dasar diidentifikasi menggunakan 3 titik pengukuran sesuai penampang model 2D yang terdapat pada Gambar 3a. Titik pengukuran merupakan posisi elektroda yang menjadi acuan dalam menentukan jenis batuan penyusun bawah permukaan pada setiap Lintasan pengukuran. Titik 1 berada pada posisi elektroda $80,5 \mathrm{~m}$. Pada titik ini terdapat lapisan batuan dasar jenis
Andesite dengan nilai tahanan jenis 440,5 m - 7598 m diduga terdapat pada kedalaman lebih dari $8,5 \mathrm{~m}$. Andesite memiliki tahanan jenis berkisar antara 170 $4,5 \times 10^{4}{ }^{[9]}$. Titik 2 berada pada posisi elektroda $140 \mathrm{~m}$ tepatnya pada titik sounding. Pada titik ini tidak terdapat batuan dasar, karena pada kedalaman lebih diduga terdapat jenis batuan sedimen lainnya. Titik 3 yang berada pada posisi elektroda $230 \mathrm{~m}$. Lapisan terakhir diduga adanya batuan dasar jenis Andesite dengan nilai tahanan jenis 440,5 $\mathrm{m}$ - $7598 \mathrm{~m}$ terdapat pada kedalaman lebih dari 13,4 m.

Gambar $3 b \quad$ memperlihatkan penampang 2D bawah permukaan dengan kedalaman yang dicapai adalah 48,7 $\mathrm{m}$. Lintasan 1 memiliki rentangan nilai tahanan jenis dari 9,96 $\mathrm{m}-39.039 \mathrm{~m}$ dengan persentase kesalahan 2,8 \% pada iterasi ke 7. Batuan penyusun pada Lintasan 1 diidentifikasi menggunakan 4 sounding. Sounding 1 berada pada jarak $63 \mathrm{~m}$, titik ini diidentifikasi memiliki 5 jenis lapisan batuan yaitu Clay, Sandstone, Limestone, Andesite dan Granite. Granite terdapat pada kedalaman lebih dari 7,8 m.

Sounding utama berada pada jarak 140 $\mathrm{m}$ dari titik awal pengukuran. Sounding utama diidentifikasi memiliki 5 jenis lapisan yaitu Clay, Sandstone, Limestone, Andesite dan Granite. Lapisan Granite terdapat pada kedalaman 11,7 m sampai 17,2 m. Sounding 3 yang berada pada jarak $164 \mathrm{~m}$ dan pada Sounding 4 yang berada pada jarak $232 \mathrm{~m}$ diduga juga tidak terdapat batuan jenis batuan dasar dan diidentifikasi memiliki 2 jenis batuan yaitu Sandstone, dan Limestone.

\section{Lintasan 2}

Lintasan 2 memiliki panjang Lintasan $315 \mathrm{~m}$, dimulai pada koordinat $00^{\circ} 17^{\prime} 43,6^{\prime \prime}$ LS dan $\quad 100^{\circ} 21^{\prime} 18,4$ " BT dengan ketinggian 923 mdpl sampai koordinat $00^{\circ}$ 17' 50,3" LS dan $100^{\circ} 21$ ' $11,5^{\prime \prime}$ BT dengan ketinggian 931 mdpl dengan 
spasi elektroda 5 meter. Gambar 4a menunjukkan penampang 2D Lintasan 2.

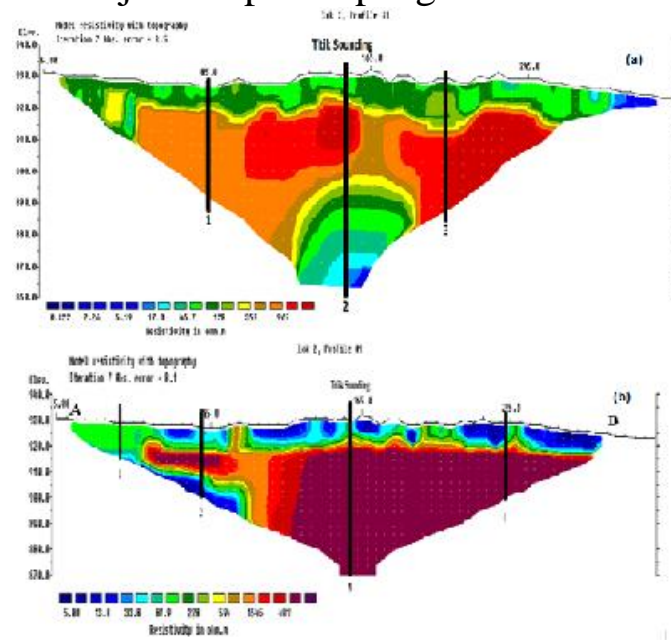

Gambar 4. Penampang Model 2D Lintasan 2 dengan Konfigurasi Dipole-dipole dan Wenner

Berdasarkan Gambar 4a dapat dilihat penampang $2 \mathrm{D}$ bawah permukaan sepanjang Lintasan 2 dengan kedalaman yang dicapai adalah $63,5 \mathrm{~m}$. Lintasan 2 memiliki rentangan nilai tahanan jenis dari 0,41 m 1277 m dengan persentase kesalahan 8,5 $\%$ pada iterasi ke 7 . Lintasan 2 memiliki standar deviasi $0,1 \%$ dan $8,1 \%$.

Batuan dasar pada Lintasan 2 diidentifikasi dengan menggunakan 3 titik. Titik 1 berada pada posisi elektroda $85 \mathrm{~m}$. Lapisan terakhir diduga adanya batuan dasar jenis Andesite dengan nilai tahanan jenis $352 \mathrm{~m}$ - $2645 \mathrm{~m}$. Batuan dasar jenis Andesite terdapat pada kedalaman lebih dari 9,9 m. Andesite memiliki tahanan jenis berkisar antara $170-4,5 \times 10^{4}[9]$. Titik 2 berada pada posisi elektroda 157,5 m tepatnya pada titik sounding. Pada titik ini tidak terdapat batuan dasar, karena pada kedalaman lebih diduga terdapat jenis batuan sedimen lainnya. Titik 3 yang berada pada posisi elektroda $237,5 \mathrm{~m}$. Lapisan terakhir diduga adanya batuan dasar jenis Andesite terdapat pada kedalaman lebih dari $13,6 \mathrm{~m}$ dengan nilai tahanan jenis $352 \mathrm{~m}$ $2645 \mathrm{~m}$.
Gambar 4b menunjukkan penampang 2D menggunakan Konfigurasi Wenner Lintasan 2. Kedalaman yang dicapai Lintasan 2 adalah 53,9 m. Lintasan 1 memiliki rentangan nilai tahanan jenis dari 2,36 $\mathrm{m}-435.644 \mathrm{~m}$ dengan persentase kesalahan $8,1 \%$ pada iterasi ke 7 .

Batuan penyusun pada Lintasan 2 diidentifikasi menggunakan 4 sounding. Sounding 1 berada pada jarak $42 \mathrm{~m}$ dari titik awal pengukuran. Titik ini diidentifikasi memiliki 2 jenis lapisan batuan yaitu Clay, dan Sandstone, dan diduga tidak terdapat batuan dasar. Sounding 2 berada pada jarak $80 \mathrm{~m}$ dari titik awal pengukuran. Batuan dasar jenis Andesit dan Granite terdapat pada kedalaman lebih $11,8 \mathrm{~m}$

Sounding utama berada pada jarak 157,5 m di-identifikasi memiliki 4 jenis batuan yaitu Clay, Sandstone, Limestone, dan Andesite. Lapisan Andesite terdapat pada kedalaman $9,1 \mathrm{~m}$ sampai $10,5 \mathrm{~m}$. Sounding 4 yang berada pada jarak $242 \mathrm{~m}$ di-identifikasi memiliki 4 jenis batuan yaitu Clay, Sandstone, Limestone, dan Andesite. Lapisan Andesite terdapat pada kedalaman 10,4 m sampai 11,4 $\mathrm{m}$ dan diduga tidak terdapat batuan dasar karena terdapat batuan dasar jenis sedimen lainnya dibawah lapisannya.

\section{Lintasan 3}

Lintasan 3 memiliki panjang $315 \mathrm{~m}$, dimulai pada koordinat $00^{\circ} 17,11,4$ " LS dan $100^{\circ} 21$ ' 12,8 " BT dengan ketinggian 932 mdpl sampai koordinat 00 28'05,7” LS dan 100 21'47,9' BT dengan ketinggian 935 mdpl dengan spasi elektroda 5 meter. Gambar 5 menunjukkan penampang 2D Lintasan 3. 


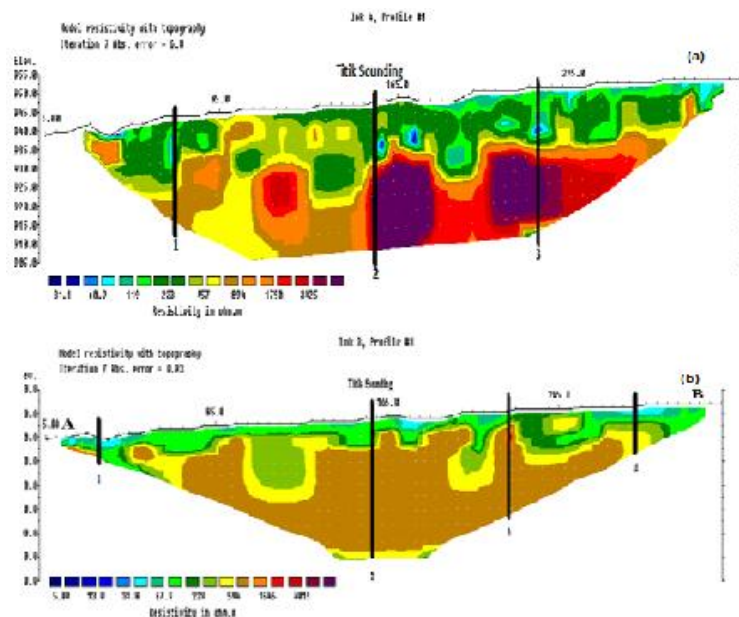

Gambar 5. Penampang Model 2D Lintasan 3 dengan Konfigurasi Dipole-dipole dan Wenner

Berdasarkan Gambar 5a dapat dilihat penampang 2D bawah permukaan sepanjang Lintasan 3 dengan kedalaman yang dicapai adalah 41,5 m. Lintasan 3 memiliki rentangan nilai tahanan jenis dari 13,5 m 6966 m dengan persentase kesalahan 6,9 $\%$ pada iterasi ke 7 . Lintasan 3 memiliki standar deviasi $0,1 \%$ dan 5,8 \%.

Batuan dasar pada Lintasan 3 diidentifikasi dengan menggunakan 3 titik. Titik 1 berada pada posisi elektroda $64 \mathrm{~m}$. Lapisan terakhir diduga adanya batuan dasar jenis Andesite dengan nilai tahanan jenis $345 \mathrm{~m}-6809 \mathrm{~m}$. Andesite terdapat pada kedalaman lebih dari $14 \mathrm{~m}$. Andesite memiliki tahanan jenis berkisar antara 170 $4,5 \times 10^{4}{ }^{[9]}$. Titik 2 berada pada posisi elektroda $157,5 \mathrm{~m}$ tepatnya pada titik sounding. Lapisan terakhir diduga adanya batuan dasar jenis Andesite terdapat pada kedalaman lebih dari $14,1 \mathrm{~m}$. Titik 3 yang berada pada posisi elektroda 227,5 m. Lapisan terakhir diduga adanya batuan dasar jenis Andesite terdapat pada kedalaman lebih dari 13,5 m $345 \mathrm{~m}$ - $6809 \mathrm{~m}$. Batuan dasar pada Lintasan umumnya terdapat pada kedalaman lebih dari $14 \mathrm{~m}$.

Gambar 5b menunjukkan penampang 2D Lintasan 3. Batuan penyusun pada
Lintasan 3 diidentifikasi menggunakan 4 sounding. Sounding 1 berada pada jarak 30 $\mathrm{m}$, titik ini diidentifikasi memiliki 4 jenis lapisan batuan yaitu Clay, Sandstone, Limestone, dan Andesite. Tidak terdapat batuan dasar pada lapisan ini. Sounding utama berada pada jarak 157,5 $\mathrm{m}$ dan Sounding 3 berada pada jarak $220 \mathrm{~m}$ dari titik awal pengukuran, diduga tidak terdapat batuan dasar. Titik ini diidentifikasi memiliki 2 jenis lapisan batuan yaitu Sandstone, dan Limestone.

\section{Lintasan 4}

Lintasan 4 memiliki panjang $315 \mathrm{~m}$, pada koordinat $00^{\circ} 17,20,2$ " LS dan $100^{\circ}$ 21' 29,0" BT dengan ketinggian $930 \mathrm{mdpl}$ sampai koordinat $\quad 00^{\circ} 17^{\prime} 55,9^{\prime \prime}$ LS dan $100^{\circ} 21$ ' 33,7" BT dengan ketinggian 949 mdpl dengan spasi elektroda 5 meter. Gambar 6 menunjukkan penampang 2D Lintasan 4.

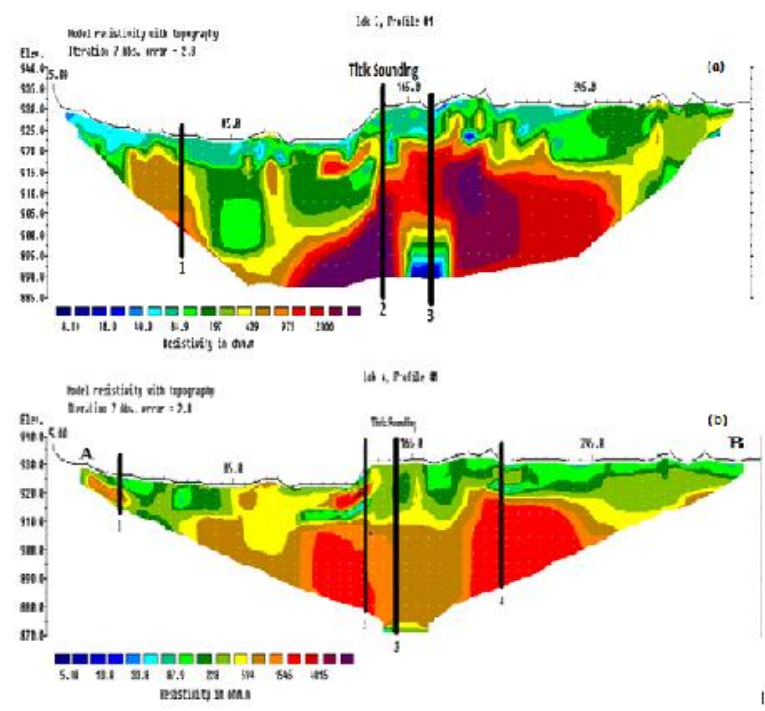

Gambar 6. Penampang Model 2D Lintasan 4 dengan Konfigurasi Dipole-dipole dan Wenner

Berdasarkan Gambar 6a dapat dilihat penampang 2D bawah permukaan sepanjang Lintasan 4 dengan kedalaman yang dicapai adalah $43 \mathrm{~m}$. Lintasan 4 memiliki rentangan nilai tahanan jenis dari 4,05 $\mathrm{m}-$ $3176 \mathrm{~m}$ dengan persentase kesalahan 2,8 $\%$ pada iterasi ke 7 . Lintasan 4 memiliki standar deviasi $0,1 \%$ dan $4,6 \%$. Pada 
Lintasan 4 identifikasi batuan dasar menggunakan 2 titik pengukuran yang berdekatan antara titik 2 dan 3 . Titik 2 dan 3 dirancang berdekatan pada penampang model 2D Lintasan 4 dikarenakan pada titik 3 diduga terdapat jenis material titik yang berbeda dengan titik 2 dilihat dari kontras warna dan nilai tahanan jenis.

Batuan dasar pada Lintasan 4 diidentifikasi dengan menggunakan 3 titik. Titik 1 berada pada posisi elektroda $62,5 \mathrm{~m}$. Lapisan terakhir diduga adanya batuan dasar jenis Andesite terdapat pada kedalaman lebih dari 9,46 m dengan nilai tahanan jenis $439 \mathrm{~m}-4811 \mathrm{~m}$. Titik 2 berada pada posisi elektroda $157,5 \mathrm{~m}$ tepatnya pada titik sounding. Lapisan terakhir diduga adanya batuan dasar jenis Andesite terdapat pada kedalaman lebih dari 7,46 $\mathrm{m}$ dengan nilai tahanan jenis $439 \mathrm{~m}-4811 \mathrm{~m}$. Titik 3 yang berada pada posisi elektroda $170 \mathrm{~m}$. Lapisan Andesite terdapat pada kedalaman 12,9 m sampai 30,8 $\mathrm{m}$ dengan ketebalan 17,9 m. Batuan Andesite pada titik bukan termasuk kedalam batuan dasar, karena pada lapisan yang lebih dalam ditemukan jenis batuan seperti, seperti Sandstone dan Limestone.

Gambar 6b menunjukkan penampang 2D Lintasan 4. Kedalaman yang dicapai pada Lintaasan 4 adalah $57,93 \mathrm{~m}$. Lintasan 4 memiliki rentangan nilai tahanan jenis dari 21,22 m sampai 7.790,6 $\mathrm{m}$ dengan persentase kesalahan $2,8 \%$ pada iterasi ke 7.

Batuan penyusun pada Lintasan 4 diidentifikasi menggunakan 4 sounding. Sounding 1 berada pada jarak $35 \mathrm{~m}$, titik ini diidentifikasi memiliki 3 jenis lapisan batuan yaitu Sandstone, Limestone dan Andesit. Andesite terdapat pada kedalaman 6 ,4 m sampai 9,1 m.

Sounding 2 berada pada jarak $145 \mathrm{~m}$ dari titik awal pengukuran.Titik ini diidentifikasi memiliki 4 jenis lapisan batuan yaitu Clay,Sandstone, Limestone dan Andesite. Andesite terdapat pada kedalaman
4,7 m sampai 5,3 m, pada kedalaman 7,9 m sampai 9,1 m dan pada kedalaman 19,9 m sampai 49,7 m. Lapisan Granite terdapat pada kedalaman 5,3 m sampai kedalaman 7,9 m. Pada Sounding utama dan Sounding 4 yang berada pada jarak $205 \mathrm{~m}$ berada pada jarak $157,5 \mathrm{~m}$ diidentifikasi tidak terdapat batuan dasar

\section{Lintasan 5}

Lintasan 5 memiliki panjang $315 \mathrm{~m}$, pada koordinat $00^{\circ} 17$ ' 39,7 " LS dan $100^{\circ}$ 21' 01,8” BT dengan ketinggian $939 \mathrm{mdpl}$ sampai koordinat $00^{\circ} 17^{\prime} 49,2$ " LS dan $100^{\circ}$ 21 ' 05,1" BT dengan ketinggian $957 \mathrm{mdpl}$ dengan spasi elektroda 5 meter. Gambar 7 menunjukkan penampang 2D Lintasan 5.

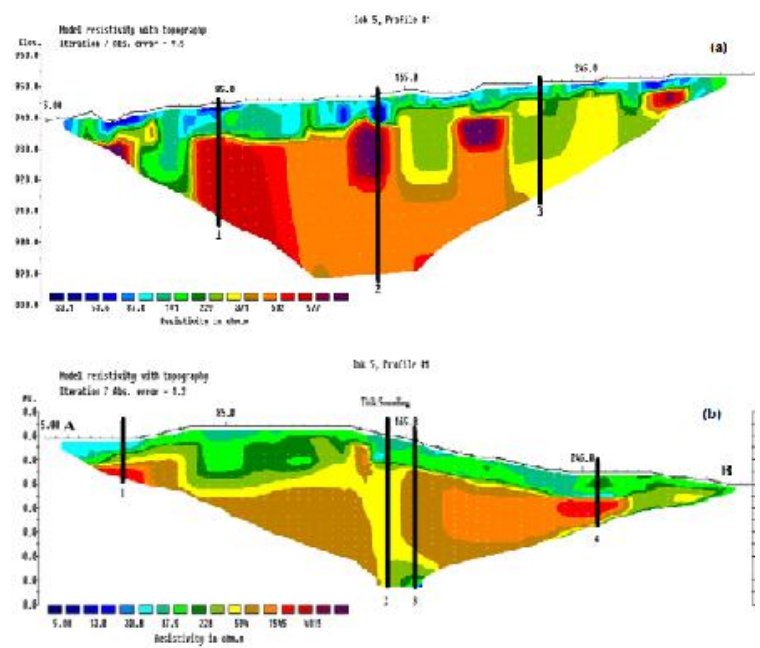

Gambar 7. Penampang Model 2D Lintasan 5 dengan Konfigurasi Dipole-dipole dan Wenner

Berdasarkan Gambar 7a dapat dilihat penampang 2D bawah permukaan sepanjang Lintasan 5 dengan kedalaman yang dicapai adalah $\quad 53 \mathrm{~m}$. Lintasan 5 memiliki rentangan nilai tahanan jenis dari 16,5 m 1585 m dengan persentase kesalahan 9,5 $\%$ pada iterasi ke 7. Lintasan 5 memiliki standar deviasi $0,1 \%$ dan $0,2 \%$.

Terdapat 3 titik untuk mengidentifikasi jenis batuan pada Lintasan 5. Titik 1 berada pada posisi elektroda $85 \mathrm{~m}$. Lapisan terakhir diduga adanya batuan dasar jenis Andesite terdapat pada kedalaman 
lebih dari $8,4 \mathrm{~m}$ dengan nilai tahanan jenis 486,5 m - $1585 \mathrm{~m}$. Titik 2 berada pada posisi elektroda $157,5 \mathrm{~m}$ tepatnya pada titik sounding. Lapisan terakhir diduga adanya batuan dasar jenis Andesite terdapat pada kedalaman lebih dari $8,9 \mathrm{~m}$. Titik 3 yang berada pada posisi elektroda $220 \mathrm{~m}$. Pada titik 3 tidak terdapat batuan dasar, karena pada kedalaman lebih diduga terdapat jenis batuan sedimen.

Gambar 7b menunjukkan penampang 2D Lintasan 5. Kedalaman yang dicapai Lintasan 5 adalah 47,93 m. Lintasan 5 memiliki rentangan nilai tahanan jenis dari 9,41 $\mathrm{m}-2.027,7 \mathrm{~m}$ dengan persentase kesalahan 1,2\% pada iterasi ke 7 .

Batuan penyusun pada Lintasan 5 diidentifikasi menggunakan 4 sounding. Sounding 1 berada pada jarak $40 \mathrm{~m}$, titik ini diidentifikasi memiliki 4 jenis lapisan batuan yaitu Clay, Sandstone, Limestone, dan Andesite. Batuan dasar jenis andesite Andesite terdapat pada kedalaman lebih dari $9,2 \mathrm{~m}$.

Sounding utama berada pada jarak 157,5 m dan Sounding 3 yang berada pada jarak $170 \mathrm{~m}$ dari titik awal pengukuran, diduga tidak terdapat batuan dasar pada titik ini. Sounding 4 yang berada pada jarak 252 $\mathrm{m}$ di-identifikasi memiliki 4 jenis batuan yaitu Clay, Sandstone, Limestone, dan Andesite. Andesite terdapat pada kedalaman $12,8 \mathrm{~m}$ sampai $22,3 \mathrm{~m}$.

\section{B. Pembahasan}

Interpretasi data dilakukan menggunakan metode inversi Robust 2-D data Geolistrik konfigurasi Dipole-dipole dan metode inversi Smoothness-Constraint Least Squares data Geolistrik konfigurasi Wenner

Identifikasi jenis batuan dasar pada kelima Lintasan pengukuran didapatkan berdasarkan harga nilai tahanan jenis dari hasil pengukuran dan Tabel tahanan jenis. Kedalaman batuan dasar didapatkan berdasarkan identifikasi dari penampang model 2D pada masing-masing Lintasan pengukuran. Pada penampang model 2D terdapat variasi warna yang menunjukkan harga tahanan jenis untuk mengidentifikasi jenis batuan. Pada penampang model 2D dapat dihitung kedalaman batuan dasar sesuai batasan warna yang telah diidentifikasi.

Lintasan 1 memiliki rentangan nilai tahanan jenis dari 4,665 m - 7598 m dengan persentase kesalahan 7,8 \% untuk konfigurasi Dipole-dipole dan 9,96 m 39.039 m dengan persentase kesalahan 2,7 $\%$ untuk konfigurasi Wenner. Berdasarkan hasil interpretasi data pengukuran, telah diduga batuan dasar dari beberapa titik daerah dekat permukaan bumi disusun oleh lapisan batuan. Titik 1 dan 3 pada Lintasan 1 diduga adanya batuan dasar jenis Andesite dengan menggunakan kongfigurasi Dipoledipole. Lapisan batuan Andesite yang paling dekat dengan permukaan bumi terdapat pada titik 1 berada pada jarak $80,5 \mathrm{~m}$ pada kedalaman lebih dari $8,5 \mathrm{~m}$. Titik 3 pada jarak $230 \mathrm{~m}$ terdapat batuan Andesite pada kedalaman lebih dari 23,4 m. Pada konfigurasi Wenner batuan dasar jenis Andesite terdapat pada titik 80,5 m dengan kedalaman lebih dari 7,3 m.

Lintasan 2 memiliki rentangan nilai tahanan jenis dari $0,41 \mathrm{~m}-6809 \mathrm{~m}$ dengan persentase kesalahan 8,5\% untuk konfigurasi Dipole-dipole dan 2,36 m 435,644 $\mathrm{m}$ dengan persentase kesalahan $8,1 \%$ untuk konfigurasi Wenner. Pada konfigurasi Dipole-dipole, batuan dasar jenis Andesite ditemukan pada titik $85 \mathrm{~m}$ dengan kedalaman lebih dari 9,9 m dan pada titik 237,5 m dengan kedalaman lebih dari 13,6 m. Pada konfigurasi Wenner batuan dasar jenis Andesite dengan kedalaman lebih dari $11,8 \mathrm{~m}$ terdapat pada titik $85 \mathrm{~m}$. Sedangkan pada titik 237,5 m tidak ditemukan adanya batuan dasar.

Lintasan 3 memiliki rentangan nilai tahanan jenis dari 13,5 m - $6966 \mathrm{~m}$ dengan persentase kesalahan 6,9 \% untuk konfigurasi Dipole-dipole dan 36,1 m 2.527,9 m dengan persentase kesalahan adalah $0,93 \%$ untuk konfigurasi Wenner. 
Berdasarkan hasil interpretasi data pengukuran, Batuan dasar terdapat pada 3 titik yaitu pada $64 \mathrm{~m}, 157,5 \mathrm{~m}$, dan 227,5 m dengan kedalaman rata-rata lebih dari 13,5 m. Sedangkan pada lintasan ini, tidak ditemukan batuan dasar untuk konfigurasi Wenner.

Lintasan 4 memiliki rentangan nilai tahanan jenis dari 4,05 $\mathrm{m}-4811 \mathrm{~m}$ dengan persentase kesalahan $2,8 \%$ untuk konfigurasi Dipole-dipole dan 21,22 m 7.790,6 m dengan persentase kesalahan $2,8 \%$ untuk konfigurasi Wenner. Berdasarkan hasil interpretasi data pengukuran, Batuan dasar terdapat pada 2 titik yaitu pada $62,5 \mathrm{~m}$ dan $157,5 \mathrm{~m}$ dengan kedalaman lebih dari 19,46 m dan 17,46 m. Sedangkan pada lintasan ini, Batuan dasar juga tidak ditemukan untuk konfigurasi Wenner.

Lintasan 5 memiliki rentangan nilai tahanan jenis dari 16,5 m - $1585 \mathrm{~m}$ dengan persentase kesalahan 9,5\% untuk konfigurasi Dipole-dipole dan 9,41 m 2.207,7 m dengan persentase kesalahan $1,2 \%$ untuk konfigurasi Wenner. Lapisan batuan Andesite yang paling dekat dengan permukaan bumi terdapat pada titik 1 pada jarak $85 \mathrm{~m}$ pada kedalaman lebih dari $8,4 \mathrm{~m}$. Titik 2 pada jarak 157,5 m pada kedalaman lebih dari $8,9 \mathrm{~m}$. Titik 1 dan 2 diduga terdapat batuan dasar jenis Andesite. Pada konfigurasi Wenner batuan dasar jenis Andesite terdapat pada titik $85 \mathrm{~m}$ dengan kedalaman lebih dari 9,2 m. Analisis identifikasi batuan dasar pada setiap Lintasan ditunjukkan pada Tabel 2.

Berdasarkan Tabel 2 dapat dilihat bahwa rentang nilai tahanan jenis batuan pada tiap Lintasan hampir mendekati sama dengan didapatkan penetrasi kedalaman yang bervariasi. Letak batuan dasar jenis Andesite yang paling dangkal terdapat pada Lintasan 1 untuk konfigurasi Wenner dengan kedalaman lebih dari 7,3 m di titik pengukuran $80,5 \mathrm{~m}$ dengan nilai tahanan jenis $9,96 \mathrm{~m}-39.039 \mathrm{~m}$ dan letak batuan dasar jenis Andesite yang paling dalam terdapat pada Lintasan 1 dengan kedalaman lebih dari 23,4 m untuk konfigurasi Dipole-dipole di titik pengukuran $170 \mathrm{~m}$ dengan nilai tahanan jenis 440,5 m-7598 m. Keberadaan batuan dasar ini sangat berguna sebagai acuan dalam pembangunan infrastruktur didaerah tempat melakukan pengukuran.

Tabel 1. Nilai Tahanan Jenis dan Kedalaman Batuan Dasar Andesite dan pada tiap Lintasan pengukuran dengan Konfigurasi Dipole-dipole dan Wenner.

\begin{tabular}{|c|c|c|c|c|c|}
\hline \multirow[b]{2}{*}{ Lintasan } & \multirow{2}{*}{$\begin{array}{c}\text { Titik Pengukuran } \\
\text { (in) }\end{array}$} & \multicolumn{2}{|c|}{ Kanfygurasi Diquie-diquie } & \multicolumn{2}{|c|}{ Konfigurasi Wenner } \\
\hline & & $\begin{array}{c}\text { Tahanan Jenis } \\
(\Omega \mathrm{m})\end{array}$ & Kedalaman (m) & $\begin{array}{c}\text { Tahangn Janis } \\
(\Omega m)\end{array}$ & Kedalaman (III) \\
\hline \multirow[b]{2}{*}{1} & 80,5 & \multirow{2}{*}{$441,5-7598$} & Lebih dari 3,5 & \multirow[b]{2}{*}{$9,95-39.039$} & Lebih dari 73 \\
\hline & 230 & & Lebih dari 23,4 & & \begin{tabular}{|l|} 
Tidalk terdapat \\
battun dasar
\end{tabular} \\
\hline \multirow[b]{2}{*}{2} & 85 & \multirow[b]{2}{*}{$352-6309$} & Lebih dari 9,9 & \multirow[b]{2}{*}{$2: 36-435.544$} & Lebih deri 11,8 \\
\hline & 237,5 & & Lebih dari 13,6 & & $\begin{array}{l}\text { licalk terdapat } \\
\text { batuan dasar }\end{array}$ \\
\hline \multirow{3}{*}{3} & 64 & \multirow{3}{*}{$345-6509,3$} & Lebli darl l4 & \multirow{3}{*}{$36,1-2.527,9$} & \multirow{3}{*}{$\begin{array}{l}\text { Tidak terdapat } \\
\text { batuan dasar }\end{array}$} \\
\hline & 157,5 & & Lebih dari 14,1 & & \\
\hline & 227,5 & & \begin{tabular}{|l|} 
Lebih dari 13,5 \\
\end{tabular} & & \\
\hline \multirow{2}{*}{4} & 6,5 & \multirow{2}{*}{$439-4811$} & Lebih dari 19,46 & \multirow{2}{*}{$21,22-7.790,6$} & \multirow{2}{*}{$\begin{array}{l}\text { Tidak terdapat } \\
\text { batuan dasar }\end{array}$} \\
\hline & 157,5 & & T.ehih dari 17,46 & & \\
\hline 5 & 157,5 & $436.5-1585$ & $\begin{array}{l}\text { Lebih deri } 3,4 \\
\text { Lebih dari } 3,9\end{array}$ & $9.41-2.027,7$ & $\begin{array}{l}\text { Tidak perdapat } \\
\text { hartanan dacar }\end{array}$ \\
\hline
\end{tabular}

Hasil Interpretasi menunjukkan bahwa batuan dasar di Bukit Apit Puhun Kecamatan Guguk Panjang Kota Bukittinggi memiliki nilai tahanan jenis yang cukup tinggi yaitu berkisar antara $\quad 352 \mathrm{~m}$ 7598 m. Nilai tahanan jenis yang cukup besar disebabkan batuan dasar memilliki nilai porositas dan permeabilitas yang rendah. Nilai porositas dan permeabilitas yang rendah menyebabkan arus listrik sulit mengalir kedalam batuan karena kandungan air yang dimiliki batuan dasar sangat sedikit bahkan tidak ada. Umunya batuan dasar pada daerah penelitian ini diduga berada pada kedalaman lebih dari $13 \mathrm{~m}$. Batuan dasar tersebut menjadi lapisan-lapisan batuan yang berada diatasnya. 


\section{KESIMPULAN}

Berdasarkan hasil yang diperoleh dari penelitian ini, maka dapat ditarik beberapa kesimpulan sebagai berikut :

1. Batuan dasar pada lintasan pengukuran ditemukan pada setiap lintasan pengukuran dengan tahanan jenis berbeda. Batuan dasar tersebut diinterpretasikan sebagai Andesite. Berdasarkan hasil pengukuran nilai tahanan jenis batuan Andesite pada kelima lintasan pengukuran berkisar antara $345 \mathrm{~m}-39.039 \mathrm{~m}$.

2. Kedalaman batuan dasar pada setiap lintasan berbeda. Letak batuan dasar jenis Andesite yang paling dalam terdapat pada Lintasan 1 dengan kedalaman lebih dari 23,4 m untuk konfigurasi Dipole-dipole di titik pengukuran $170 \mathrm{~m}$ dengan nilai tahanan jenis $440,5 \quad m-7598 \quad m$ dan letak batuan dasar jenis Andesite yang paling dangkal terdapat pada Lintasan 1 untuk konfigurasi Wenner dengan kedalaman lebih dari 7,3 $\mathrm{m}$ di titik pengukuran $80,5 \mathrm{~m}$ dengan nilai tahanan jenis $9,96 \mathrm{~m}-39.039 \mathrm{~m}$.

\section{UCAPAN TERIMA KASIH}

Penulis mengucapkan terima kasih kepada DP2M DIKTI yang telah mendanai penelitian ini melalui Pekan Kreativitas Mahasiswa (PKM) tahun 2014 dengan judul Analisis Aquifer Desa Bugek Menggunakan Metode Inversi Least Square Getanis Untuk Mengatasi Krisis Air Bersih di Kecamatan Gupan Kota Bukittinggi. Terima kasih juga kepada rekan-rekan yang telah yang telah memberikan motivasi dalam penyelesaian tugas akhir dan artikel ini.

\section{DAFTAR PUSTAKA}

[1]. Natawidjaja,

Danny Hilman.2008.Pedoman Analisis Bahaya dan Risiko Bencana Gempabumi.Dipersiapkan untuk BNPB /SCDRR.
[2]. Munir, Moch. 1995. Geologi dan Mineralogi Tanah. Malang: Pustaka Jaya.

[3]. Rafferty, John.P 2012. Geological Sains. New York: Britannica Educational Publishing.

[4]. Samodra, Hanang. 2008. "Geologi Batuan Dasar Gunung Ciremai Jawa Barat”. Jurnal Geologi Indonesia 4(5). Hlm. 279-287.

[5]. Nukdin, Ernita. 2012. 'Geologi dan Studi Pengaruh Batuan Dasar terhadap Deposit Nikel Laterit Daerah Taringgo Kecamatan Pomalaa, kabupaten Kolaka Propinsi Sulawesi Tenggara'. Jurnal. Ilmiah MTG, Vol.8, No.2, Juli 2012. Hlm. 99-109.

[6]. Sircar, Anirbid. (2004). "Hydrocarbon Production from Fractured Basement Formations". Jurnal. Current Science. Vol.87. No.2. Hlm 147-151.

[7]. Gutmanis, Jon. (2010). "Hydrocarbon Production From Fractured Basement Formation". Jurnal. Geoscience Limited Versi 9. Hlm. 1-40.

[8]. Hanifah, Kemas Ali. 2010. Dasardasar Ilmu Tanah. Raja Grafindo Persada: Jakarta.Price, Monica \& Kevin Walsh. 2005. Pocket Nature Rocks and Minerals. London: Dorling Kindersley.

[9]. Telford, W.M. Geldart, L.P, Sheriff R.E and Keys, D.A. 1990. Applied Geophysics. USA : Cambridge University Press.

[10]. Nisa, Khoirun dkk. 2012.”Aplikasi Metode Geolistrik Tahanan Jenis untuk Menentukan Zona Intrusi Air laut di Kecamatan Genuk Semarang". Berkala Fisika. Vol. 15, No.1, Januari 2012. Hlm 7-14.

[11]. Akmam. (2004). "Existence of Spring in Batulimbak Village Simawan Kecamatan Rambatan Kabupaten Tanahdatar". Jurnal Prosiding Seminar PPD Forum HEDS 2004 Bidang MIPA, ISBN 979-95726-7-3. Hlm 593-608.

[12]. Marescot, Laurent. (2009). Electrical Surveying. Swiss: University of Fribourg. 
[13]. Sharma, P.V. 1997. Environmental and Engineering Geophysics. Cambridge University Press, United Kingdom.

[14]. GF Instruments. 2007. Short Guide for Resistivity Imaging. Jecna: Geophysical Equipment and Services.

[15]. Reynolds, J.M. 1997. An Introduction to Applied andEnvironmental Geophysics. New York: Jhon Geophysicsin Hidrogeological and Wiley andSons Ltd.

[16]. Gubbins, David. 2004. Time Series Analysis dan Inverse Theory for Geophysicists. New York : The Press Sydndicate of the University of Cambridge.

[17]. Guitton, Antoine. Symes, William. (2003). "Robust Inversion of Seismic Data Using the Huber Norm". Jurnal. Geophysics Vol 68. No 4 July-August 2003. Hlm. 1310-1319.

[18]. Dobrin, Milton B, Salvit Carl H. 1998. Introduction to Geophysical Prospecting. Singapore : McGraw-Hill Internasional editions

[19]. Israil et al. 2004. "Determining Sharp layer Boundaries From Straightforward Inversion of Resistivity Sounding Data". Jurnal. J.Ind.Geophys. Union. Vol.8, No.2, pp. 125 - 133.

[20]. Loke, M. H. 2004. 2-D and 3-D electrical imaging surveys. $\mathrm{G}$ 